\title{
Invertase, glucose oxidase and catalase for converting sucrose to fructose and gluconic acid through batch and membrane- continuous reactors
}

\author{
Aline Ramos da Silva, Ester Junko Tomotani, Michele Vitolo* \\ Department of Biochemical and Pharmaceutical Technology, Faculty of Pharmaceutical Sciences, University of São Paulo
}

\begin{abstract}
Conversion of sucrose into fructose and gluconic acid using invertase, glucose oxidase and catalase was studied by discontinuous (sequential or simultaneous addition of the enzymes) and continuous (simultaneous addition of the enzymes in a $100 \mathrm{kDa}$-ultrafiltration membrane reactor) processes. The following parameters were varied: concentration of enzymes, initial concentration of substrates (sucrose and glucose), $\mathrm{pH}$, temperature and feeding rate (for continuous process). The highest yield of conversion $(100 \%)$ was attained through the discontinuous (batch) process carried out at $\mathrm{pH} 4.5$ and $37^{\circ} \mathrm{C}$ by the sequential addition of invertase $(14.3 \mathrm{U})$, glucose oxidase $(10,000 \mathrm{U})$ and catalase $(59,000 \mathrm{U})$.
\end{abstract}

Uniterms: Sucrose/conversion. Fructose. Gluconic acid. Invertase. Glucose oxidase. Catalase.

\begin{abstract}
Neste trabalho estudou-se a conversão da sacarose em frutose e ácido glicônico, usando as enzimas invertase, glicose oxidase e catalase, através do emprego de processo descontínuo (com adição sequencial ou simultânea das enzimas) e contínuo (adição simultânea das enzimas em reator com membrana acoplado à membrana de ultrafiltração de $100 \mathrm{kDa}$ ). Os parâmetros variados foram: a concentração das enzimas, a concentração inicial dos substratos (sacarose e glicose), o pH, a temperatura e a vazão específica de alimentação (processo contínuo). Obteve-se rendimento de 100\%, quando a conversão foi conduzida por processo descontínuo em $\mathrm{pH} 4,5$ e a $37^{\circ} \mathrm{C}$ com adição seqüencial das enzimas invertase (14,3 U), glicose oxidase $(10.000 \mathrm{U})$ e catalase $(59.000 \mathrm{U})$.
\end{abstract}

Unitermos: Sacarose/conversão. Frutose. Àcido glicônico. Invertase. Glicose oxidase. Catalase.

\section{INTRODUCTION}

Enzyme catalysis is a controlled process, which can be performed discontinuously (batch) or continuously, under mild $\mathrm{pH}$ and temperature conditions. Thereby, $\mathrm{pH}$ and temperature sensitive substances may be efficiently transformed into desired products. Enzymes - in soluble or insoluble forms - are also highly selective catalysts and may be used at the same time to carry out simultaneous reactions. In general, enzymatic processes do not generate environmental pollutants (Tomotani, Vitolo, 2010).

Enzymatic processes are an alternative to chemical, extractive or microbial synthesis in order to obtain chemical, food and/or pharmaceutical products. Bioca-

Correspondence: M. Vitolo, Deapartamento de Tecnologia BioquímicoFarmacêutica, Faculdade de Ciências Farmacêuticas, Universidade de Paulo, Av. Prof. Lineu Prestes 580, B.16-Cidade Universitária, 05508-000 - São Paulo - SP, Brasil. E-mail: michenzi@usp.br talysis may often replace the traditional processes based on extraction (requires handling of a large amount of raw-materials), fermentation (requires strict aseptic procedures throughout the process) and chemical synthesis (high energy consumption, low enantioselectivity and high environmental pollution potential) (Tomotani, Vitolo, 2007).

Biocatalysis has been used in chemical transformations on the basis of one enzyme and one substrate to produce a desired product. Multienzyme systems, represented mainly by intact cells and biosensors (with immobilized enzymes), have practical feasibility (Panke, Wubbolts, 2005; Kennedy, et al., 2007). Bienzymic systems have been very useful in reactions catalyzed by dehydrogenases which require coenzymes in the reduced or oxidized form (Andreotti, et al., 2010). However, systems consisting of three or more enzymes are rarely described in the literature. The possibility of obtaining fructooligosaccharides 
(FOS) and gluconic acid using sucrose, by the action of invertase, glucose oxidase and catalase was described by Sheu et al. (2001).

Sucrose is a low cost commodity widely produced in Brazil (annual production s of over 30 million tons), which is subject to competition among several countries and to oscillation of the world market. Transformation of sucrose into more valuable commercial products - such as fructose and gluconic acid, both imported partially or totally by Brazil - may contribute to the diversification of the national sugar alcohol market. The availability of this alternative would be advantageous in the event that world demand for sugar became low, causing a longer storage period of this product - an undesirable situation for two main reasons: saturation of storage areas in warehouses and deterioration of the product due to its high hygroscopic characteristics. Conversion of surplus sugar into fuel-ethanol would also not be financially advantageous for the distilleries because processed sugar has a higher aggregate value than fuel-ethanol.

The aim of this work was to evaluate the discontinuous reactor as well as a continuous-membrane reactor for the direct conversion of sucrose into fructose and gluconic acid for sequential or simultaneous action of invertase, glucose oxidase and catalase.

\section{MATERIAL AND METHODS}

\section{Material}

The enzymes used were: invertase (EC.3.2.1.26) from Saccharomyces cerevisiae (purchased from BIO$\mathrm{CON}^{\circledR}-1 \mathrm{~mL}$ of invertase presents $1430 \mathrm{U}$, where $1 \mathrm{U}=1 \mathrm{mg} \mathrm{TRS} / \mathrm{min}$, measured at $\mathrm{pH} 4.6$ and at $37^{\circ} \mathrm{C}$; TRS- total reducing sugars); glucose oxidase (EC.1.1.3.4) from Aspergillus niger (from SIGMA ${ }^{\circledR}-1$ solid g has $5,000 \mathrm{U}$, where $1 \mathrm{U}=1 \mu \mathrm{mol}$ of $\mathrm{H}_{2} \mathrm{O}_{2}$ formed $/ \mathrm{min}$, measured at $\mathrm{pH} 5.1$ and at $37^{\circ} \mathrm{C}$ ) and catalase (EC 1.11.1.6) from bovine liver $\left(\right.$ SIGMA $^{\circledR}-1$ solid $\mathrm{mg}$ has $2,950 \mathrm{U}$, where $1 \mathrm{U}=1 \mu \mathrm{mol}$ of $\mathrm{H}_{2} \mathrm{O}_{2}$ consumed /min, measured at $\mathrm{pH} 4.6$ and $37^{\circ} \mathrm{C}$ ). All of the other chemicals were analytical grade.

\section{Methods}

Effect of $\mathrm{pH}$, temperature and substrate concentration on the activity of invertase and glucose oxidase (GO)

\section{- Invertase}

In a $250 \mathrm{~mL}$-beaker, $108 \mathrm{~mL}$ of $0.01 \mathrm{M}$ acetate buffer ( $\mathrm{pH} 3.5 ; 4.0 ; 4.5 ; 5.0 ; 5.5$ or 6.0$)$ was added, after immersion in a water bath at a set temperature $\left(30^{\circ} \mathrm{C}\right.$, $37^{\circ} \mathrm{C}, 40^{\circ} \mathrm{C}$ or $45^{\circ} \mathrm{C}$ ). After 10 minutes, an amount of sucrose was dissolved under agitation (100 rpm) in order to reach an initial concentration of $4,6,10,15,20,30,40$ or $50 \mathrm{mM}$. After 5 minutes, a sample $(0.5 \mathrm{~mL})$ of the sucrose solution was taken (time zero), followed by addition of $12 \mathrm{~mL}$ of the invertase solution (3.43 U). Aliquots ( 0.5 $\mathrm{mL}$ ) were taken every minute, up to 6 min of total reaction. Total reducing sugar concentration (TRS) was determined according to Arruda, Vitolo (1996).

Enzyme stability was evaluated by incubating an invertase solution ( $3.43 \mathrm{U}$ ) for $0 \mathrm{~h} ; 0.5 \mathrm{~h} ; 1 \mathrm{~h} ; 10 \mathrm{~h} ; 20 \mathrm{~h}$ and $30 \mathrm{~h}$ at $\mathrm{pH} 4.5$ and $37^{\circ} \mathrm{C}$. The residual invertase activity was determined as previously described.

\section{- $\quad$ Glucose Oxidase}

In a $250 \mathrm{~mL}$-beaker, $125 \mathrm{~mL}$ of $0.01 \mathrm{M}$ acetate buffer ( $\mathrm{pH} 4.0 ; 4.5 ; 5.0$ or 5.5$)$ was added, after immersion in a water bath at a set temperature $\left(30^{\circ} \mathrm{C}, 37^{\circ} \mathrm{C}, 40{ }^{\circ} \mathrm{C}\right.$ or $45^{\circ} \mathrm{C}$ ). During the entire process, air was bubbled into the reaction medium, in order to keep it saturated with oxygen (3 - $4 \mathrm{mg} / \mathrm{L})$. An aliquot of the medium $(1 \mathrm{~mL})$ was removed as a blank. After 10 minutes, an amount of glucose was dissolved under agitation $(100 \mathrm{rpm})$ in order to reach an initial concentration of $4,8,10,15,20$ or $25 \mathrm{mM}$. A sample of $1 \mathrm{~mL}$ of the glucose solution was taken to measure the initial concentration of $\mathrm{H}_{2} \mathrm{O}_{2}(\mathrm{t}=0)$. Subsequently, $25 \mathrm{~mL}$ of the $\mathrm{GO}$ solution ( $180 \mathrm{U}$ ) was added to the beaker and aliquots of $1 \mathrm{~mL}$ were taken every $10 \mathrm{~min}$ up to $1 \mathrm{~h}$ of total reaction. Each sample was immersed in a boiling water bath in order to stop the reaction. Measurement of $\mathrm{H}_{2} \mathrm{O}_{2}$ formed during the reaction was made according to Tomotani et al (2005).

Enzyme stability was evaluated by incubating GO solution (180U) for $0 \mathrm{~h} ; 0.5 \mathrm{~h} ; 1 \mathrm{~h} ; 10 \mathrm{~h} ; 20 \mathrm{~h}$ and $30 \mathrm{~h}$ at $\mathrm{pH} 4.5$ and $37^{\circ} \mathrm{C}$. The residual GO activity was determined as previously described.

\section{Effect of catalase on residual hydrogen peroxide determination}

In a $250 \mathrm{~mL}$-beaker, $100 \mathrm{~mL}$ of $0.01 \mathrm{M}$ acetate buffer ( $\mathrm{pH} 4.5$ ) was added and introduced into a water bath at $37^{\circ} \mathrm{C}$. An aliquot $(1 \mathrm{~mL})$ was taken to be used as a blank. A sample of $6 \mathrm{~mL}$ taken from a solution containing $30 \mathrm{~mL}$ of $\mathrm{H}_{2} \mathrm{O}_{2}(6.12 \mathrm{~g} / \mathrm{L})$ was added to the beaker at time zero. An aliquot of $1 \mathrm{~mL}$ was taken to determine the initial hydrogen peroxide concentration. The reaction was started by adding a sample of $4 \mathrm{~mL}$, which was taken from a 20 -mL buffered solution containing catalase $(29,500 \mathrm{U})$. Every 5 minutes, samples of $6 \mathrm{~mL}$ and $4 \mathrm{~mL}$ of $\mathrm{H}_{2} \mathrm{O}_{2}$ and catalase solutions, respectively, were added 
to the beaker until all the volumes of both solutions had been added after a 20-min reaction. Aliquots of $1 \mathrm{~mL}$ for the residual $\mathrm{H}_{2} \mathrm{O}_{2}$ determination were taken before each addition of hydrogen peroxide and catalase. The total reaction time was 30 minutes. In order to stop the reaction, eppendorf tubes containing the samples were immersed in a boiling water bath. The residual amount of $\mathrm{H}_{2} \mathrm{O}_{2}$ was determined at $240 \mathrm{~nm}$ according to Tomotani et al (2005).

In order to verify the UV absorption at $240 \mathrm{~nm}$ by catalase, which could interfere in the $\mathrm{H}_{2} \mathrm{O}_{2}$ determination, a similar assay was performed, without addition of $\mathrm{H}_{2} \mathrm{O}_{2}$.

\section{Hydrolysis of sucrose in a discontinuous process (batch)}

In a $250 \mathrm{~mL}$-beaker, $108 \mathrm{~mL}$ of $0.01 \mathrm{M}$ acetate buffer ( $\mathrm{pH} 4.5)$ was added, after immersion in a water bath at $37^{\circ} \mathrm{C}$. After 10 minutes, an amount of sucrose was dissolved under agitation of $100 \mathrm{rpm}$ in order to achieve initial concentrations of $2,4,8,16$ or $32 \mathrm{~g} / \mathrm{L}$. After 5 minutes, $12 \mathrm{~mL}$ of a buffered solution of invertase (1.43 U, $2.86 \mathrm{U}$, $5.72 \mathrm{U}$ or $14.3 \mathrm{U}$ ) was added to the beaker and aliquots $(0.5 \mathrm{~mL})$ were removed every $20 \mathrm{~min}$ up to $1 \mathrm{~h}$ of total reaction. Samples were then incubated in a boiling water bath for $5 \mathrm{~min}$. Total reducing sugar concentration (TRS) was determined according to Arruda, Vitolo (1996). The beginning of the reaction $(\mathrm{t}=0)$ corresponded to the first sample removed before addition of invertase.

\section{Oxidation of glucose in a discontinuous process (batch)}

In a $250 \mathrm{~mL}$-beaker, $105 \mathrm{~mL}$ of $0.01 \mathrm{M}$ acetate buffer ( $\mathrm{pH} 4.5)$ was added, after immersion in a water bath at $37^{\circ} \mathrm{C}$. During the entire process, air was bubbled into the reaction medium in order to keep it saturated with oxygen (3- $4 \mathrm{mg} / \mathrm{L})$. A sample of $1 \mathrm{~mL}$ was removed to be used as a blank. After 10 minutes, an amount of glucose was dissolved under an agitation of $100 \mathrm{rpm}$ to achieve initial concentrations of $1,2,4,8$, or $16 \mathrm{~g} / \mathrm{L}$. An aliquot $(1 \mathrm{~mL})$ was taken to determine the initial hydrogen peroxide concentration (time zero). Subsequently, $25 \mathrm{~mL}$ of a buffered solution containing glucose oxidase $(1,000 \mathrm{U}$, $2,500 \mathrm{U}, 5,000 \mathrm{U}$ or $10,000 \mathrm{U}$ ) was added, followed by the addition of $2 \mathrm{~mL}$ of buffered catalase solution (5,900 U), which was repeated every $20 \mathrm{~min}$ up to $80 \mathrm{~min}$ of reaction. Aliquots $(1 \mathrm{~mL})$ of the medium were removed, before the addition of catalase solution, every 20 minutes up to $2 \mathrm{~h}$ of total reaction. Immediately after withdrawal, each sample was immersed in a boiling water bath for $5 \mathrm{~min}$. Residual $\mathrm{H}_{2} \mathrm{O}_{2}$ and consumption of TRS were determined according to Arruda, Vitolo (1996) and Tomotani et al (2005), respectively.
Bioconversion of sucrose into fructose and gluconic acid in a discontinuous process with sequential addition of invertase and glucose oxidase/catalase

In a $150 \mathrm{~mL}$-beaker, $96 \mathrm{~mL}$ of $0.01 \mathrm{M}$ acetate buffer ( $\mathrm{pH}$ 4.5) was added, after immersion in a water bath at $37^{\circ} \mathrm{C}$. An amount of $3.84 \mathrm{~g}$ of sucrose was dissolved under agitation $(100 \mathrm{rpm})$ to reach an initial concentration of $32 \mathrm{~g} / \mathrm{L}$. After 5 minutes, $24 \mathrm{~mL}$ of an aqueous solution of invertase was added (14.3 U). Every 10 minutes, $1 \mathrm{~mL}$ of the sample was removed up to $30 \mathrm{~min}$ of total reaction. Before addition of the enzyme, an aliquot $(1 \mathrm{~mL})$ was taken to determine the initial amount of TRS (time zero). Subsequently, $55 \mathrm{~mL}$ of the hydrolyzed solution was taken from the original recipient and placed into a $100 \mathrm{~mL}-$ beaker. Twenty milliliters of a solution containing glucose oxidase $(10,000 \mathrm{U})$ and catalase $(59,000 \mathrm{U})$ were added. Aliquots $(1 \mathrm{~mL})$ were removed every 20 minutes, up to $2 \mathrm{~h}$ of total reaction, for analytical purposes.

Bioconversion of sucrose into fructose and gluconic acid in a discontinuous process with simultaneous addition of invertase and glucose oxidase/catalase

In a $150 \mathrm{~mL}$-beaker, $61 \mathrm{~mL}$ of $0.01 \mathrm{M}$ acetate buffer ( $\mathrm{pH} 4.5$ ) was added, after immersion in a water bath at $37^{\circ} \mathrm{C}$. An amount of $3.84 \mathrm{~g}$ of sucrose was dissolved under agitation (100 rpm) to reach an initial concentration of $32 \mathrm{~g} / \mathrm{L}$. After 5 minutes, $59 \mathrm{~mL}$ of a buffered solution containing the enzymes was added [invertase (14.3 U), glucose oxidase $(10,000 \mathrm{U})$ and catalase $(59,000 \mathrm{U})]$. A sample $(1 \mathrm{~mL})$ was taken every 20 minutes, up to $2 \mathrm{~h}$ of total reaction, for analytical purposes. The blank was the sample $(1 \mathrm{~mL})$ taken before addition of the enzymes.

Bioconversion of sucrose into fructose and gluconic acid by the simultaneous action of invertase, glucose oxidase and catalase in a membrane-continuous reactor

The continuous tests were performed in a membrane reactor (an ultrafiltration cell - Millipore ${ }^{\circledR}$ ) coupled with a $100 \mathrm{kDa}$-ultrafiltration membrane. The system was pressurized with compressed air and a dissolved oxygen concentration of 3-4 mg/L was maintained throughout the process. The operational reactor volume was set to $300 \mathrm{~mL}$. The enzymes [invertase (18 U, $32 \mathrm{U}, 72 \mathrm{U}$ or $143 \mathrm{U}), \mathrm{GO}(10,000 \mathrm{U})$ and catalase 59,000 U)] were added simultaneously and the outlet solution from the reactor was collected every hour in an Erlenmeyer flask. Tests were performed at $\mathrm{pH} 4.5$ and at $30^{\circ} \mathrm{C}, 37^{\circ} \mathrm{C}, 40^{\circ} \mathrm{C}$ or $45^{\circ} \mathrm{C}$. Residual $\mathrm{H}_{2} \mathrm{O}_{2}$ and TRS were measured, as previously cited. 


\section{Analytical determinations}

- Determination of total reducing sugars (TRS)

TRS was measured using the Somogyi-Nelson method as described previously (Arruda, Vitolo, 1996).

- Determination of hydrogen peroxide

Hydrogen peroxide concentration was determined from the absorbance at $240 \mathrm{~nm}$. The standard-linear equation was $\mathrm{y}=1.66 \mathrm{x}+4.24 \times 10^{-3}(\mathrm{r}=0.99998)$, where $\mathrm{y}$ and $\mathrm{x}$ are the absorbance and the amount of $\mathrm{H}_{2} \mathrm{O}_{2}(\mathrm{mg})$, respectively. Concentration of the standard solution used to obtain the standard plot was varied between 0.0608 and $0.608 \mathrm{mg}$ of $\mathrm{H}_{2} \mathrm{O}_{2} / \mathrm{mL}$ (Tomotani et al., 2005).

\section{RESULTS AND DISCUSSION}

All data referring to the effect of $\mathrm{pH}$, temperature and initial substrate concentration on the activity of invertase and $\mathrm{GO}$ was achieved by plotting concentration of TRS and/or $\mathrm{H}_{2} \mathrm{O}_{2}$ against reaction time, that is, all activities corresponded to initial velocities. For instance, Figure 1 shows the formation of TRS and $\mathrm{H}_{2} \mathrm{O}_{2}$ over time of sucrose hydrolysis and glucose oxidation reactions carried out as described above. Thus, activities of invertase $\left(\mathrm{v}_{\mathrm{I}}\right)$ and glucose oxidase $\left(\mathrm{v}_{\mathrm{GO}}\right)$ corresponded to $0.060 \mathrm{mg}$ TRS/min.mL and $0.0107 \mathrm{mg} \mathrm{H}_{2} \mathrm{O}_{2} /$ min.mL, respectively. The activity of invertase is approximately six-fold higher than GO activity which means that hydrolysis of sucrose occurs faster than glucose oxidation. This fact should be taken into account when both enzymes are used together.

It was previously established that a concentration of hydrogen peroxide above $1.3 \mathrm{mM}(0.0442 \mathrm{mg} / \mathrm{mL})$ causes a noncompetitive inhibitory effect on the activity of GO (Tomotani et al., 2005). A complicating factor is that hydrogen peroxide is an obligatory by-product formed when glucose is oxidized to gluconic acid by GO. As the initial glucose concentration employed in this work was $16 \mathrm{~g} / \mathrm{L}$, the inhibitory concentration limit of hydrogen peroxide should certainly have been reached and GO activity would have been reduced. For this reason, catalase was used as an auxiliary enzyme, to remove hydrogen peroxide.

However, due to the fact that catalase possesses a metallic ion as a prosthetic group (Scott, 1975), it presents, in principle, the capability of absorbing UV-light at $240 \mathrm{~nm}$, the same wavelength used to determine the concentration of residual hydrogen peroxide. Therefore, all multienzymatic assays, except for the continuous process, were accompanied by a test with catalase only, in order to correct the absorbance at $240 \mathrm{~nm}$ ("blank assay").

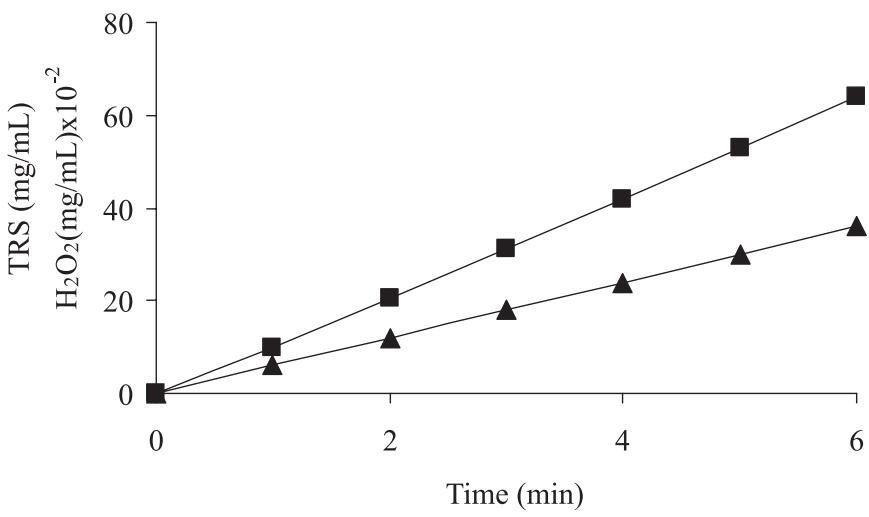

FIGURE 1 - Formation of TRS $(\boldsymbol{\Delta})$ and $\mathrm{H}_{2} \mathrm{O}_{2}(\boldsymbol{\nabla})$ resulting from sucrose hydrolysis by invertase and glucose oxidation by GO, respectively, as a function of time. The equations of straight lines are: $\left.(\mathrm{TRS})=0.060 \times \mathrm{xt}-3.6 \times 10^{-5}(\mathrm{r}=0.99995)\right]$ and $\left(\mathrm{H}_{2} \mathrm{O}_{2}\right)$ $=0.0107 \times \mathrm{xt}-6.6 \times 10^{-4}(\mathrm{r}=0.9998)$.

When a multienzymatic process is intended, factors that affect activities of the enzymes, such as $\mathrm{pH}$ and temperature, must have be as close as possible to their optimum values. Therefore, by comparing the variation of invertase and $\mathrm{GO}$ activities against $\mathrm{pH}$, it was observed that the $\mathrm{pH}_{\text {optimum }}$ for both enzymes was 4.5 (Figure 2). This was a quite good result insofar as the aim of this work was the direct conversion of sucrose into fructose and gluconic acid, using the previously mentioned enzymes. The $\mathrm{pH}$ value obtained is in agreement with the literature, in the range of pH 4.5-5.0 for both enzymes (Vitolo, 2004; Milovanovic et al., 2007; Bao et al., 2001). Catalase - an auxiliary enzyme in the process - was used at the $\mathrm{pH}$ of the operational condition ( $\mathrm{pH} 4.5$ ), although the highest activity and the lowest light absorption at $240 \mathrm{~nm}$ are reached at $\mathrm{pH}$ 6.8-7.0 (Kresse, 1990; Da Silva, 2010). A lower catalase activity at $\mathrm{pH} 4.5$ was compensated by using a larger amount of enzyme than that actually needed at $\mathrm{pH}$ 7.0.

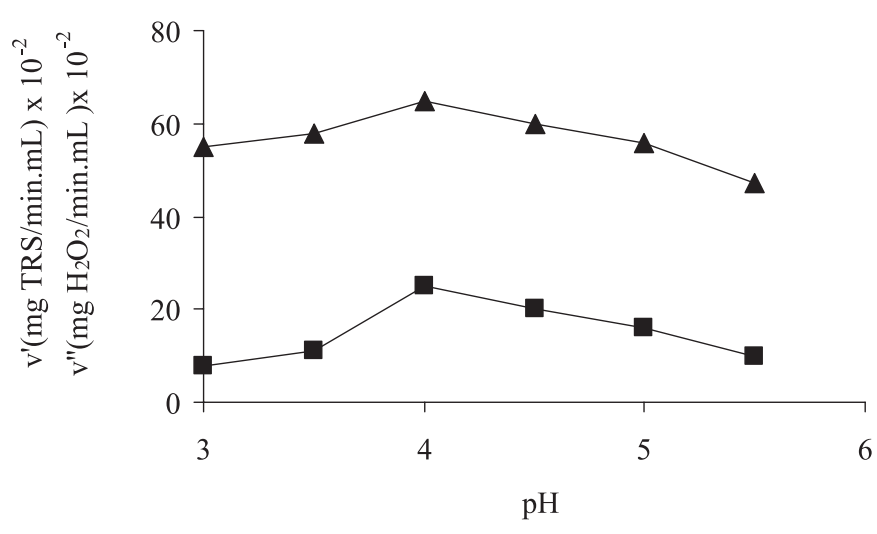

FIGURE 2 - Effect of pH on activity of invertase ( $\boldsymbol{\Delta})$ and GO (घ) at $37^{\circ} \mathrm{C}$. 
Table 1 shows that an increase of temperature from $30{ }^{\circ} \mathrm{C}$ to $45^{\circ} \mathrm{C}$ promoted approximate 1.9 and 2.3 fold increases in invertase and $\mathrm{GO}$ activities, respectively. By applying the conventional Arrhenius' method to the data in Table 1, the activation energies for the reactions catalyzed by invertase and $\mathrm{GO}$ were calculated. These were equal to $31 \mathrm{~kJ} / \mathrm{mol}$ and $44 \mathrm{~kJ} / \mathrm{mol}$, respectively. Therefore, sucrose hydrolysis by invertase requires about $30 \%$ less energy than glucose oxidation by GO. This result corroborates the highest activity of invertase over GO, as observed previously (Figure 1). Glucose oxidase followed the Van't Hoff's law, insofar as its activity doubled when the temperature increased $10^{\circ} \mathrm{C}$ (temperature interval of $30^{\circ} \mathrm{C}$ and $40^{\circ} \mathrm{C}$ ) (Table 1). Such a result is seldom described in the literature, because enzymes generally do not follow Van't Hoffs' law (Fullbrook, 1996).

TABLE I - Activities of invertase $\left(\mathrm{v}_{\mathrm{I}}\right)$ and glucose oxidase $\left(\mathrm{v}_{\mathrm{GO}}\right)$ at $\mathrm{pH} 4.5$ and different temperatures

\begin{tabular}{lcc}
\hline $\mathrm{T}\left({ }^{\circ} \mathrm{C}\right)$ & $\begin{array}{c}\mathrm{V}_{\mathrm{I}} \times 10^{-2} \\
(\mathrm{mg} \mathrm{TRS} / \text { min.mL })\end{array}$ & $\begin{array}{c}\mathrm{v}_{\mathrm{GO}} \times 10^{-3} \\
\left(\mathrm{mg} \mathrm{H}_{2} \mathrm{O}_{2} / \mathrm{min} \cdot \mathrm{mL}\right)\end{array}$ \\
\hline 30 & 4.03 & 0.90 \\
37 & 5.73 & 1.10 \\
40 & 6.55 & 1.80 \\
45 & 7.68 & 2.10 \\
\hline
\end{tabular}

Applying the conventional method of Lineweaver-Burk, the kinetic constants for both enzymes were determined (invertase: $\mathrm{K}_{\mathrm{M}}=28.5 \mathrm{mM}$ and $\mathrm{V}_{\max }=0.064 \mathrm{mg} \mathrm{TRS} / \mathrm{min} \cdot \mathrm{mL}$ and $\mathrm{GO}: \mathrm{K}_{\mathrm{M}}=20.3 \mathrm{mM}$ and $\mathrm{V}_{\text {max }}=0.0012 \mathrm{mg} \mathrm{H}_{2} \mathrm{O}_{2} /$ min.mL) (Figure 3). The calculated $\mathrm{K}_{\mathrm{M}}$ values for invertase and GO lie within the ranges mentioned in the literature, i.e., 26-40 mM (Milovanovic et al., 2007; Dizge et al., 2008) and 18-32 mM (Simpson et al., 2007; Hoshi et al., 2007), respectively.

From Table II, it can be seen that both enzymes were stable after $30 \mathrm{~h}$ at $\mathrm{pH} 4.5$ and $37^{\circ} \mathrm{C}$. Under these conditions, it could be speculated that both enzymes do not suffer modification in their respective molecular structures. According to the literature, invertase may have kept its molecules aggregated (De Queiroz et al., 1996), whereas GO kept its prosthetic groups $\mathrm{Fe}^{+2} / \mathrm{Fe}^{+3}$ and $\mathrm{FAD} / \mathrm{FADH}_{2}$ in the reduced and oxidized forms, respectively (Tomotani, 2006; Simpson et al., 2007; Bao et al., 2001). Consequently, conversion of sucrose into fructose and gluconic acid in a continuous multi enzymatic membrane reactor for $15 \mathrm{~h}$, would most likely occur with the main enzymes ( $\mathrm{GO}$ and invertase) in their ideal molecular conformation.
TABLE II - Residual activities of invertase and GO determined for $30 \mathrm{~h}$ at $\mathrm{pH} 4.5$ and $37^{\circ} \mathrm{C}$

\begin{tabular}{lcc}
\hline Test $(\mathrm{h})$ & $\begin{array}{c}\mathrm{V}_{\mathrm{I}} \times 10^{-2} \\
(\mathrm{mg} \mathrm{TRS} / \mathrm{mL} \cdot \mathrm{min})\end{array}$ & $\begin{array}{c}\mathrm{v}_{\mathrm{GO}} \times 10^{-3} \\
\left(\mathrm{mg} \mathrm{H}_{2} \mathrm{O}_{2} / \mathrm{min} . \mathrm{mL}\right)\end{array}$ \\
\hline 0 & 7.55 & 1.44 \\
0.5 & 7.60 & 1.40 \\
1 & 7.50 & 1.39 \\
10 & 7.62 & 1.41 \\
20 & 7.24 & 1.46 \\
30 & 7.30 & 1.43 \\
\hline
\end{tabular}

Sucrose hydrolysis by invertase, oxidation of glucose by GO, and decomposition of hydrogen peroxide by catalase, take place at different enzymatic velocities with invertase being the fastest. Invertase was therefore taken as a reference to adjust the reaction time in order to produce the amount of glucose necessary for the subsequent oxidation reaction by GO. In addition, hydrogen peroxide, an obligatory byproduct of this reaction, should be decomposed by catalase so its presence in the reaction medium would be kept under control.

Through exploratory tests, it was observed that sucrose hydrolysis, regardless of its initial concentration, should not be less than 30 min in length (Da Silva, 2010). Otherwise, the amount of glucose formed would be extremely high for efficient oxidation by GO, while excessive foaming would occur due to formation of a high amount of molecular oxygen, resulting from decomposition of hydrogen peroxide by catalase. Such uncontrolled foaming, mainly due to GO and catalase, would interfere negatively in the performance of discontinuous (splashing of its content) and continuous (intense bubbling inside the

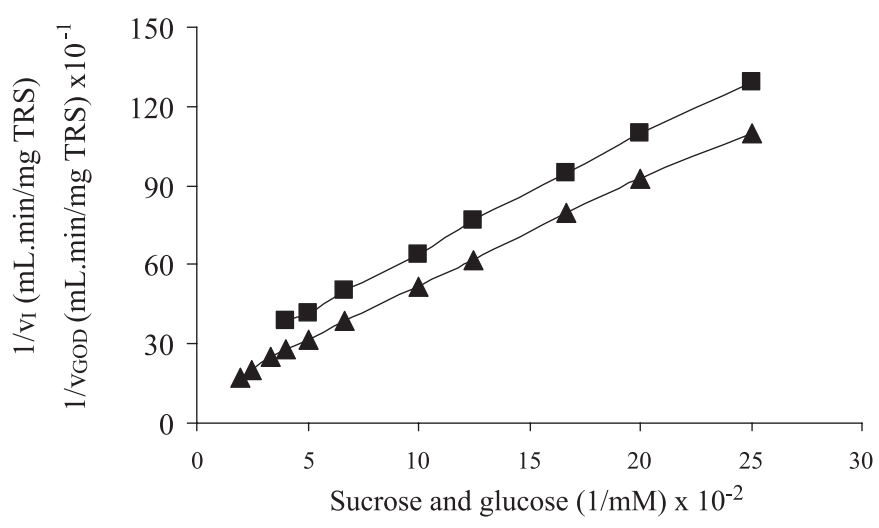

FIGURE 3 - Lineweaver-Burk's plot for calculation of kinetic constants related to invertase $(\boldsymbol{\Delta})$ and glucose oxidase $(\boldsymbol{\nabla})$. The linear regression lines for invertase and GO are: $1 / \mathrm{v}_{\mathrm{I}}=387 \mathrm{x}(1 / \mathrm{S})$ $+13.6(\mathrm{r}=0.997)$ and $1 / \mathrm{v}_{\mathrm{GO}}=4199 .(1 / \mathrm{S})+207.23(\mathrm{r}=0.994)$, respectively. 
outlet pipeline) reactors. Therefore, adjustments to the total activity of invertase and the initial concentration of sucrose were made.

Table III shows that, for a sixteen-fold increase in the initial concentration of sucrose, total invertase activity in the reaction medium should be increased ten-fold in order to achieve hydrolysis within the time interval of 30 to $60 \mathrm{~min}$. Imbalance of the sucrose concentration/total invertase activity ratio could result from the increase of aggregation of invertase molecules due to a higher amount of enzyme in the reaction medium. As previously mentioned by De Queiroz et al. (1996), the greater the invertase molecule aggregation, the higher the catalytic activity.

TABLE III - Total activity of invertase (U) for complete sucrose hydrolysis using different sucrose concentrations and respective reaction times $\left(\mathrm{t}^{*}\right)$

\begin{tabular}{lcc}
\hline Sucrose $(\mathrm{g} / \mathrm{L})$ & $\mathrm{t}^{*}(\mathrm{~min})$ & $\mathrm{v}_{\mathrm{I}}(\mathrm{U})$ \\
\hline 2 & 60 & 1.43 \\
4 & 40 & 2.86 \\
8 & 40 & 5.72 \\
16 & 30 & 10.4 \\
32 & 40 & 14.3 \\
\hline
\end{tabular}

Table IV shows that the system consisting of GO/ catalase presented suitable activities for each initial concentration of glucose. The amounts of TRS and hydrogen peroxide in the reaction media were insignificant after $2 \mathrm{~h}$ of reaction. In this work, the initial concentration of glucose to be converted was established to be $16 \mathrm{~g} / \mathrm{L}$, in order to avoid intense foaming, which would result due to the combined effect of mechanical agitation, reduction of the superficial tension (due to the presence of enzymatic proteins) and the presence of molecular oxygen (from the decomposition of $\mathrm{H}_{2} \mathrm{O}_{2}$ by catalase).

Regarding the bioconversion [sucrose/(fructose + gluconic acid)] in a discontinuous reactor (sequential addition of enzymes), sucrose was completely consumed in 30 minutes and the glucose produced was converted into gluconic acid in about 40 minutes (Figure 4).

Considering the following equation: $\mathrm{Y}=100-$ $(\mathrm{X}-50)$, where ' $\mathrm{Y}$ ' is the yield (conversion of glucose into gluconic acid) and ' $\mathrm{X}$ ' is TRS (sum of the amount of residual glucose and fructose), it was concluded from Figure $4(\mathrm{X}=50 \%)$ that glucose was totally oxidized.

In a discontinuous process [sucrose/(fructose + gluconic acid)] performed by simultaneous action of the enzymes, the yield of the oxidation of glucose, calculated through $Y=100-(X-50)$, was around $85 \%(X=65 \%)$
(Figure 5). Figure 5 shows that TRS accumulates up to $\mathrm{t}=20 \mathrm{~min}$, decreasing thereafter. This behavior reveals that sucrose hydrolysis was not a limiting step of the overall reaction. This result points to the fact that sucrose hydrolysis occurs faster than glucose oxidation, as previously discussed.

TABLE IV - Residual glucose and hydrogen peroxide concentrations resulting from glucose oxidation by GO and from decomposition of hydrogen peroxide by catalase. The glucose solutions of $1 \mathrm{~g} / \mathrm{L}, 2 \mathrm{~g} / \mathrm{L}$ and $4 \mathrm{~g} / \mathrm{L}$ were treated with $29,500 \mathrm{U}$ of catalase and with 1,000 U, 2,500 $\mathrm{U}$ and 5,000 $\mathrm{U}$ of $\mathrm{GO}$, respectively, whereas glucose solutions of $8 \mathrm{~g} / \mathrm{L}$ and $16 \mathrm{~g} / \mathrm{L}$ were treated with $10,000 \mathrm{U}$ of GO and 59,000 U of catalase.

\begin{tabular}{lccccc}
\hline $\begin{array}{l}\text { Time } \\
(\mathrm{min})\end{array}$ & 1 & 2 & 4 & 8 & 16 \\
\hline 0 & $* 1.0 / 0 * *$ & $2.0 / 0$ & $4.0 / 0$ & $8.0 / 0$ & $16 / 0$ \\
20 & $0.86 / 25$ & $1.41 / 9.0$ & $3.0 / 72$ & $4.9 / 112$ & $6.6 / 354$ \\
40 & $0.63 / 40$ & $0.65 / 7.5$ & $0.88 / 35$ & $2.43 / 76$ & $2.75 / 118$ \\
60 & $0.39 / 45$ & $0.30 / 5.4$ & $0.58 / 12$ & $0.82 / 28$ & $0.77 / 84$ \\
80 & $0.24 / 15$ & $0.080 / 1.2$ & $0.093 / 0$ & $0.30 / 13$ & $0.50 / 38$ \\
100 & $0.080 / 2$ & $0.021 / 0$ & $0 / 0$ & $0.067 / 5.2$ & $0.19 / 17$ \\
120 & $0.010 / 0.1$ & $0 / 0$ & $0 / 0$ & $0.017 / 0$ & $0.088 / 7.5$ \\
\hline
\end{tabular}

*The first value refers to the residual concentration of glucose (mg TRS $/ \mathrm{mL}$ ), whereas the second value refers to the residual concentration of $\mathrm{H}_{2} \mathrm{O}_{2}\left[(\mathrm{mg} / \mathrm{mL}) \times 10^{-3}\right]$.

Comparing the discontinuous reactor protocols related to the simultaneous and sequential addition of the enzymes, the sequential method proved more effective. When the three enzymes were used at the same time, there was a need to adjust the amounts of each enzyme, in order to balance the length of hydrolysis, oxidation and decomposition reactions.

Despite the excellent conversion obtained through the discontinuous process, there is the additional issue to consider with regard to the recycling of the enzymes. Through the discontinuous process, recovery of the catalysts would only be efficient if they were immobilized in insoluble supports, which could be easily separated from the reaction media, when necessary. Although the immobilization approach would be efficient when one enzyme was employed, it would be far less efficient when two or more enzymes were used. In the present work, two non related events might be satisfied simultaneously by the immobilization procedure, i.e., regarding invertase it would be assured that its molecules remained aggregated in octamers, a quite active form of the enzyme (Vitolo, 2004; De Queiroz et al., 1996), whereas for GO, it would 
be to guarantee its prosthetic groups in reduced $\left(\mathrm{Fe}^{+2}\right)$ and oxidized (FAD) states (Tomotani, et al., 2005). To circumvent such a limitation, an alternative approach would be using a continuous stirred-tank reactor (CSTR), in which the enzymes were in the soluble form. A promising device might be a CSTR coupled with an ultrafiltration membrane, i.e., a one-modulus membrane reactor (MR) (Neves, Vitolo, 2007; Tomotani, Vitolo, 2010).

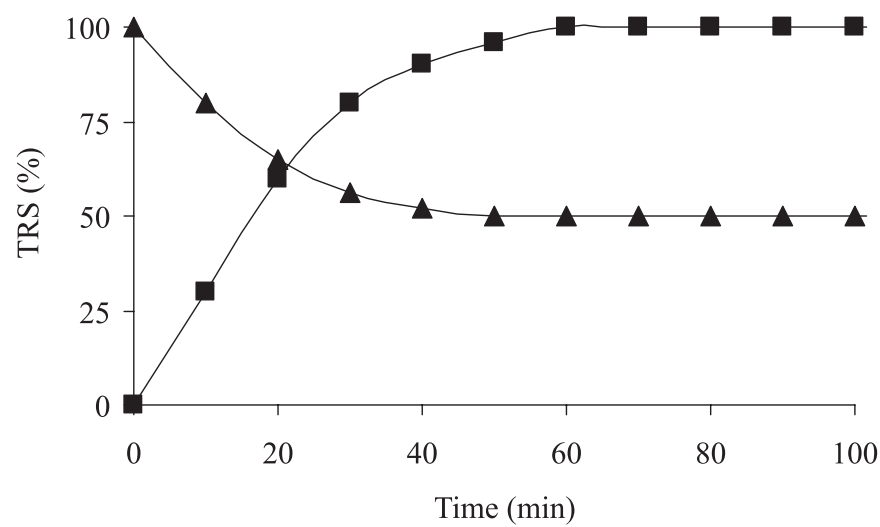

FIGURE 4 - Discontinuous process performed by sequential addition of enzymes. In the first stage $(\boldsymbol{\square})$, sucrose hydrolysis by invertase $(14.3 \mathrm{U})$ was performed. In the second stage $(\boldsymbol{\Delta})$, glucose (produced during the first stage) was oxidized to gluconic acid by $\mathrm{GO}(10,000 \mathrm{U})$. Hydrogen peroxide was decomposed by catalase $(59,000 \mathrm{U})$.

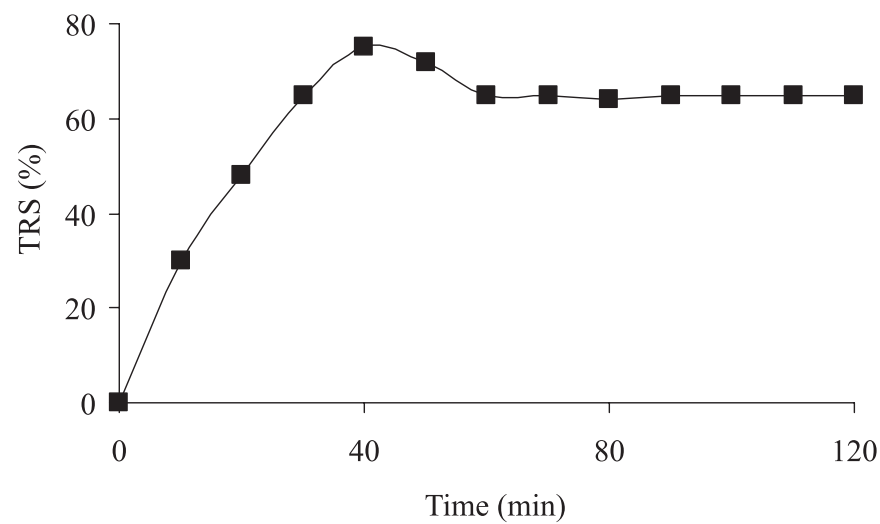

FIGURE 5 - Discontinuous process to convert sucrose to fructose and gluconic acid, performed in one step by adding invertase (14.3 U), glucose oxidase $(10,000 \mathrm{U})$ and catalase $(59,000 \mathrm{U})$ simultaneously.

The soluble forms of invertase, $\mathrm{GO}$ and catalase were used simultaneously inside an MR, which had been coupled with a $100-\mathrm{kDa}$-ultrafiltration membrane. The effects of three parameters, i.e., invertase activity, temperature and feeding rate, on the duration of the steady-state and on the conversion yield of the MR-continuous process were studied (Table V).
From Table V it is clear that temperatures higher than $37^{\circ} \mathrm{C}$ are not favorable for the establishment of the steady-state within the reactor (tests 7 and 8). Probably, the decrease in dissolved oxygen concentration in the reaction medium leads to a condition of non saturation of GO, such that its FAD prosthetic group, which after glucose oxidation becomes $\mathrm{FADH}_{2}$ (reduced form), was not completely regenerated. In the end, only a fraction of GO molecules recover their full catalytic capability, which was insufficient to sustain the continuous process at the steady-state throughout the reaction time, i.e., the equilibrium condition is not reached (Miguel et al., 2007). The highest yield (84\%) along with a steady-state duration of $11 \mathrm{~h}$ was achieved at $\mathrm{v}_{\mathrm{i}}=18 \mathrm{U}, \mathrm{D}=0.40 \mathrm{~h}^{-1}$ and $37^{\circ} \mathrm{C}$ (Table V and Figure 6). Taking into account tests 1-5, an eight-fold variation of invertase activity (from $18 \mathrm{U}$ to $143 \mathrm{U}$ ) and a 2.3 times variation in the feeding rate (from $0.32 \mathrm{~h}^{-1}$ to $0.72 \mathrm{~h}^{-1}$ ) led to a small variation in the steadystate duration (about 17\%) and to a large variation in the yield attained (from 33\% to 84\%) (Table V). As high yields remaining for long steady-state periods are envisaged through a continuous process, then it becomes clear that a compromise between $\mathrm{v}_{\mathrm{I}}$ and $\mathrm{D}$ must be found for each process carried out under specified operational conditions.

TABLE V - Continuous bioconversion in a membrane reactor performed at $\mathrm{pH} 4.5$ using an initial sucrose concentration of $32 \mathrm{~g} / \mathrm{L}$. Invertase activity, specific feeding rate (D) and temperature were varied. The activities of GO and catalase used were 10,000 $\mathrm{U}$ and 59,000 $\mathrm{U}$, respectively. The length of the stationary state and the yield obtained in each test are given.

\begin{tabular}{lccccc}
\hline Test (n) & $\mathrm{v}_{\mathrm{I}}(\mathrm{U})$ & $\begin{array}{c}\mathrm{T} \\
\left({ }^{\circ} \mathrm{C}\right)\end{array}$ & $\begin{array}{c}\mathrm{D} \\
\left(\mathrm{h}^{-1}\right)\end{array}$ & $\begin{array}{c}\text { Yield } \\
(\%)\end{array}$ & $\begin{array}{c}\text { Duration of } \\
\text { stationary state } \\
(\mathrm{h})\end{array}$ \\
\hline 1 & 143 & 37 & 0.72 & 47 & 11 \\
2 & 143 & 37 & 0.32 & 33 & 12 \\
3 & 72 & 37 & 0.53 & 73 & 10 \\
4 & 36 & 37 & 0.44 & 79 & 12 \\
5 & 18 & 37 & 0.40 & 84 & 11 \\
6 & 18 & 30 & 0.40 & 68 & 9 \\
7 & 18 & 40 & 0.42 & 73 & - \\
8 & 18 & 45 & 0.41 & 56 & - \\
\hline
\end{tabular}

On one hand, the data presented shows that conversion [sucrose/(fructose + gluconic acid)] attained through continuous and discontinuous MR processes, both carried out with the three enzymes in soluble forms, was practically the same (near 85\%). On the other hand, for the discontinuous bioconversion, in which addition of enzymes was sequential, 
the yield was $100 \%$. Therefore, a promising manner to transfer this result to a continuous MR process, would be to carry out the conversion separately by using two MRs coupled in series. In the first reactor, sucrose hydrolysis would be performed by invertase and the outlet solution (containing glucose and fructose) would be introduced into the second reactor, in which glucose would be oxidized to gluconic acid and $\mathrm{H}_{2} \mathrm{O}_{2}$ decomposed by $\mathrm{GO}$ and catalase, respectively. By doing so, immobilization of the enzymes, as required by the discontinuous process, might not be necessary, insofar as the MR can operate efficiently with several enzymes in a soluble form.

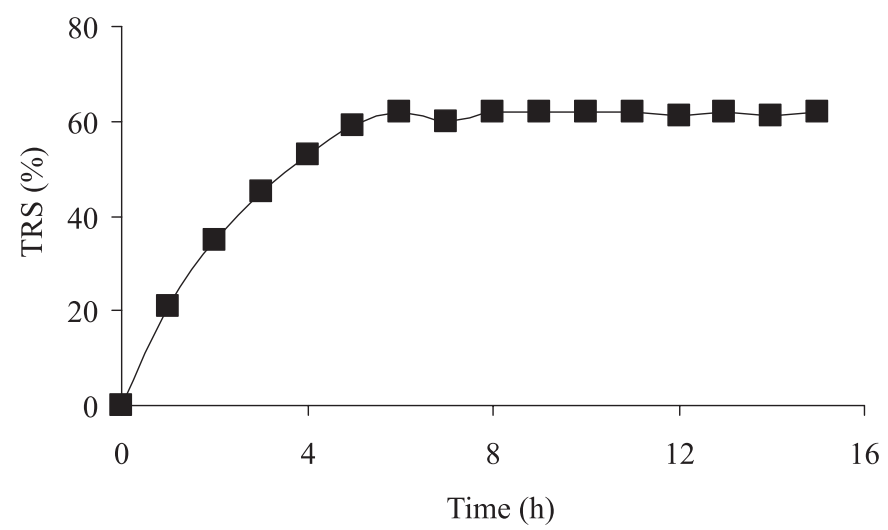

FIGURE 6 - Percentage TRS determined in outlet solution of the conversion of sucrose by simultaneous action of invertase, glucose oxidase and catalase using a continuous membrane reactor (Test 5).

\section{CONCLUSION}

The main enzymes used (invertase and GO) presented high activity at $\mathrm{pH} 4.5$ and were stable for $30 \mathrm{~h}$ at the same $\mathrm{pH}$ and at the temperature of $37^{\circ} \mathrm{C}$. The highest yield of conversion [sucrose/(fructose + gluconic acid] equal to $100 \%$, was achieved in the discontinuous process with sequential addition of the enzymes. Nonetheless, a promising yield of around $85 \%$ was also obtained in the discontinuous and continuous processes (membrane reactor) with simultaneous addition of the enzymes. Future studies of this bioconversion should involve its evaluation in a continuous process, by which two membrane reactors are connected in series, and where sucrose hydrolysis and glucose oxidation is performed sequentially.

\section{ACKNOWLEDGEMENTS}

The authors acknowledge the financial grant from FAPESP (Fundação de Amparo à Pesquisa do Estado de São Paulo) and the invaluable assessment from Philip Barsanti.

\section{REFERENCES}

ANDREOTTI, D.Z.; TOMOTANI, E.J.; VITOLO, M. The Use of dehydrogenases for regenerating $\beta$-nicotinamide adenine coenzymes through discontinuous and continuous processes. In: EUROPEAN BIOMASS CONFERENCE AND EXHIBITION, 18., Lyon, 2010. Lyon: ETA-Florence, 2010. p.1367-1370.

ARRUDA, L.M.; VITOLO, M. Characterization of invertase entrapped into calcium alginate beads. Appl. Biochem. Biotechnol., v.8, p.23-33, 1996.

BAO, J.; FURUMOTO, K.; FUKUNAGA, K.; NAKAO, K. A kinetic study on air oxidation of glucose catalyzed by immobilized glucose oxidase for production of calcium gluconate. Biochem. Eng. J., v.8, p.91-102, 2001.

Da SILVA, A.R. Multienzyme conversion of sucrose into fructose and gluconic acid in discontinuous and continuous reactors. São Paulo, 2010. 75p. [Dissertation of Master degree. Faculty of Pharmaceutical Sciences, University of São Paulo].

DE QUEIROZ, A.A.A; VITOLO, M.; DE OLIVEIRA, R.C.; HIGA, O.Z. Invertase immobilization onto radiationinduced graft copolymerized polyethylene pellets. Radiat. Phys. Chem., v.47, p.873-880, 1996.

DIZGE, N.; GUNAYDIN, O.; YILMAZ, F.; TANRISEVEN, A. Immobilization of invertase onto poly(3-methylthienyl methacrylate)/poly(3-thiopheneacetic acid) matrix. Biochem. Eng. J., v.40, p.64-71 2008.

FULLBROOK, P.D. Practical limits and prospects (kinetics). In: GODFREY, T.; WEST, S. (Eds.). Industrial enzymology. 2.ed. Ladon, UK: MacMillan Press LTD, 1966. p.516.

HOSHI, T.; SAGAE, N.; DAIKUHARA, K.; TAKAHARA, K.; ANZAI, J. Multilayer membranes via layer-by-layer deposition of glucose oxidase and Au nanoparticles on a Pt electrode for glucose sensing. Materials Science and Engineering: C, v.27, Issue 4, p.890-894, 2007.

KENNEDY, J.F.; PIMENTEL, M.C.B.; MELO, E.H.M.; LIMA-FILHO, J.L. Sucrose biosensor as an alternative tool for sugarcane Field samples. J. Sci. Food Agr., v.87, p.2266-2271, 2007. 
KRESSE, G.B. Enzymes in Analysis and Medicine, Survey. In: GERHARTZ, W. (Ed.). Enzymes in industry. Weinheim: VCH, 1990. p.153-184.

MIGUEL, A.S.M.; VITOLO, M.; PESSOA-Jr, A. Fed-batch culture of recombinant S.cerevisiae for G6PDH production. Biochem. Eng. J., v.33, p.248-252, 2007.

MILOVANOVIĆ, A.; BOŽIĆ, N.; VUJČIĆ, Z. Cell wall invertase immobilization within calcium alginate beads. Food Chem.,v.104, p.81-86 2007.

NEVES, L.M.C., VITOLO, M. Use of glucose oxidase in a membrane reactor for gluconic acid production. Appl. Biochem. Biotechnol., v.136-140, p.161-170, 2007.

PANKE, S.; WUBBOLTS, M.G. Advances in biocatalytic synthesis of pharmaceutical intermediates. Curr. Opin. Chem. Biol., v.9, p.188-194, 2005.

SCOTT, D. Oxidoredutases. In: REED, G. (Ed.) Enzymes in food processing. New York: Academic Press, 1975. p.219-254.

SHEU, D.C.; LIO, P.J.; CHEN, S.T.; LIN, C.T.; DUAN, K. Production of fructooligosaccharides in high yield using a mixed enzyme system of $\beta$-fructofuranosidase and glucose oxidase. Biotechnol. Lett., v.23, p.1499-1503, 2001.

SIMPSON, C.; JORDAAN, J.; GARDINER, N. S.; WHITELEY, C. Isolation, purification and characterization of a novel glucose oxidase from Penicillium sp. CBS 120262 optimally active at neutral pH. Protein Expr. Purif., v.51, p.260-266, 2007.
TOMOTANI, E.J. Imobilização da Invertase em resina de troca iônica (tipo Dowex ${ }^{\circledR}$ ): seu uso na modificação da sacarose. São Paulo, 2002. 161 p. [Dissertation of Master degree. Faculty of Pharmaceutical Sciences, University of São Paulo].

TOMOTANI, E.J.; VITOLO, M. Production of high-fructose syrup using immobilized invertase in a membrane reactor. J. Food Eng., v.80, p.662-667, 2007.

TOMOTANI, E.J.; NEVES, L.C.M.; VITOLO, M. Oxidation of glucose to gluconic acid by glucoseoxidase in membrane bioreactor. Appl. Biochem. Biotechnol., v.121, p.149-162, 2005.

TOMOTANI, E.J. Bioconversão de sacarose em ácido glicônico e frutose usando reator com membrana. São Paulo, 2006. 102 p. [Thesis of PhD degree. Faculty of Pharmaceutical Sciences, University of São Paulo].

TOMOTANI, E.J.; VITOLO, M. Inverted sugar syrup attained from sucrose hydrolysis using a membrane reactor. Braz. J. Pharm. Sci., v.46, n.3, p.571-577, 2010.

VITOLO, M. Invertase. In: SAID, S., PIETRO, R.C.L.R., (Eds.). Enzimas como agentes tecnológicos. Ribeirão Preto: Legis Summa, 2004. $412 \mathrm{p}$.

Received for publication on $14^{\text {th }}$ November 2010 Accepted for publication on $08^{\text {th }}$ February 2011 
